\title{
Partial Results of the Pilot Research on Developing Key Competencies of Elementary School Pupils through Interactive Whiteboard
}

\author{
Peter Brečka MonikaValentová \\ Department of Technology and Information Technologies, \\ Faculty of Education, Constantine the Philosopher University in Nitra, \\ Dražovskácesta 4, 94974 Nitra, Slovakia \\ \{pbrecka, mvalentova2\}@ukf.sk
}

\begin{abstract}
Considering the current lack of methodological source materials for accurate use of interactive whiteboards at elementary schools in Slovakia the main objective of the presented research is to develop educational strategies and models for teaching of selected subjects which will create conditions for the development of key competencies of the pupils. The article presents partial results of the pilot research on the key competencies of elementary school pupils developed through interactive whiteboard in the subject of Technics.
\end{abstract}

Keywords: key competencies, elementary education, interactive whiteboard (IWB).

\section{Introduction}

The life we are living today could be very well characterized as the age of continuous development of information and communication technologies (ICT). These have become an essential part of everyday life for all people and are gradually implemented into the educational process on every level from pre-school to university education [1].

Therefore it is important that every person possesses a certain range of key competencies [2] and it is education that plays a major role in their development. The educational basis of many member states of OECD and EU is moving towards the development of key competencies.

\section{Current State of the Issue}

Some significant factors preventing efficiency in teaching technical and science-oriented subjects at elementary schools are the lack of target-oriented educational materials for teachers aimed at the methodology of work with ICT equipment, lackof updated textbooks for pupils and also the lack of electronic interactive teaching aids. In terms of preparing future teachers in the fields of mathematics, physics and technics there are currently no study materials dealing with the described issue [3].
Schools currently make efforts to implement interactive whiteboards into educating pupils, however, often improperly and even wrongly. Considering the current transformation in the field of education towards developing key competencies, teachers lack such materials and teaching aids which would allow them to bring the changes into effect.

\section{The Focus and Methodology of the Research}

Our objective is to conduct a research aimed at the implementation of one of the progressive technologies, an interactive whiteboard, into the teaching process in the subject Technics at elementary schools.

The focus of the applied research is a gradual validation of the effect of the conducted methodology, strategies and models for teaching in practice by means of a natural experiment.

The research is carried out at selected elementary schools. The teacher lead the lessons in ways they usually do, however, with maximum use of IWB and study materials conducted by us.

The realization of the research was preceded by preparing the needed methodological materials and research equipment that will help us attain our objectives. Each member of our team has chosen the lesson topics according to the subjects in the selected grade at lower secondary level. After that, they made a presentation for IWB on each topic, a workbook (methodological guide) for the teacher, a workbook for pupils and an observation sheet.It is essential that each presentation shows such situations which help pupils develop their key competencies.

In the introduction part of the lesson the teacher informs pupils of the objectives, arrangement and methods used during the lesson. The main part of the lesson is focused on the use of IWB and completion of the tasks on the board and in the workbooks. Before the start of each lesson the teacher directs a short discussion of the issue aimed to motivate the pupils. The pupils note down the results of each task into their workbooks. Then the teacher selects a pupil to illustrate the task on the board and helps with the 
resolution. The rest of the students check the accuracy of their solution and note the number of points they obtained down to their workbooks. At the end of the lesson, the pupils count the overall number of points they obtained throughout the whole workbook and the teacher evaluates the lesson.

For each of the presentation there is a workbook for the teacher worked-out. It serves as a methodological guide according to which the teacher proceeds while teaching. It imparts information on all organisational and material requisites for teaching the given topic. Also, it contains a specifically defined lesson topic, number of lessons devoted to it, the grade for teaching and especially, specifically defined key competencies that students should develop or acquire through resolving certain tasks using the IWB.

The workbook also informs the teacher about the time frame for the realisation of particular tasks in the presentation and the amount of points each pupil can obtain for their accurate resolution. The workbook for pupils contains instructions for resolving each of the tasks on the IWB.

All listed methodical materials and research equipment were consulted with teachers at selected elementary schools where the participants of the research will evaluate them in practice.

Based on the results of past analysis [4], [5] we have selected those key competencies and skills for the subject of Technics which are shown in Table 1.

Table 1

\begin{tabular}{|c|c|}
\hline $\begin{array}{l}\text { Categories of } \\
\text { Key } \\
\text { Competencies }\end{array}$ & $\begin{array}{l}\text { Selected Key Competency, } \\
\text { Skill }\end{array}$ \\
\hline \multirow[t]{3}{*}{ Interpersonal } & Team Work (Int.-TW) \\
\hline & $\begin{array}{l}\text { Harmonic Relationships } \\
\text { (Int.-HR) }\end{array}$ \\
\hline & Efficient Work (Int.-EW) \\
\hline \multirow[t]{3}{*}{ Communicative } & $\begin{array}{l}\text { Reading Comprehension } \\
\text { (Com.-RC) }\end{array}$ \\
\hline & Speaking Skills (Com.-SS) \\
\hline & Writing Skills (Com.-WS) \\
\hline \multirow[t]{2}{*}{ Personal } & $\begin{array}{l}\text { Control over Behaviour - } \\
\text { Self-control (Per.-SC) }\end{array}$ \\
\hline & $\begin{array}{l}\text { Honesty and Responsibility } \\
\text { (Per.-HR) }\end{array}$ \\
\hline \multirow[t]{3}{*}{ Learning } & $\begin{array}{l}\text { Self-motivation and } \\
\text { Motivation of Others (L.-M) }\end{array}$ \\
\hline & Problem-solving (L.-PS) \\
\hline & $\begin{array}{l}\text { Active Participation in Task } \\
\text { Resolving (L.-AP) }\end{array}$ \\
\hline Cognitive & $\begin{array}{l}\text { Critical Thinking and } \\
\text { Evaluation (Cog.-CT) }\end{array}$ \\
\hline
\end{tabular}

A major role in the experiment is played by the observers whose task is to record the occurrence of the phenomena of key competencies during the lessons into the observation sheets. The construction of the observation sheets is similar to the one of workbooks. The person recording the phenomena - the selected key competencies is thoroughly informed about the progress of the lesson which prevents mistakes regarding the observation. The observers record the key competencies of random couples to ensure absolute objectivity and accuracy of the observed phenomena. The key competencies are recorded for each task separately.

\section{Partial Results of the Research}

The pilot research was conducted in two towns at two elementary schools in the 6th and 8th grade with the lesson topic „Wood, Its Significance and Use“, whilst the occurrence of the phenomena was recorded while resolving seven tasks.

The first school was the elementary school in HrnčiarovcenadParnou, where we were able to discover the development of key competencies as follows.

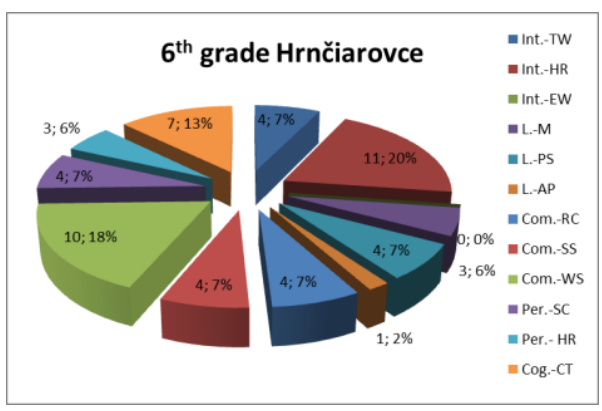

Fig. 1: Percentageoccurrence of the observed competencies in the $6^{\text {th }}$ grade in HrnčiarovcenadParnou

The percentage manifestation of the results on Fig. 1 shows that almost all the supposed key competencies evinced themselves amongst all observed groups of 6th grade pupils at elementary school in Hrnčiarovce. Most frequently they were interpersonal $(15,9 \%)$ and communicative $(19,58 \%)$ competencies. The workbooks imparted some quite difficult tasks; however, we observed personal competencies $(8,3 \%)$ as well. The behaviour of the pupils during the final notation of points obtained was honest and responsible, the pupils controlled their behaviour and there were no misunderstandings. The tasks were dynamic and interesting, however demanded a demonstration on IWB which resulted in $9,5 \%$ occurrence of learningcompetencies amongst pupils. The task designed for developing critical thinking has also proven its justification $(7,13 \%)$. While resolving the task pupils had to work with words, ideas and mental images and had to decide upon the accuracy of the results of the given task.

The frequency of occurrence of key competencies amongst the pupils of $8^{\text {th }}$ grade of the elementary school in Hrnčiarovce (Fig. 2) was in some cases higher than amongst pupils of the $6^{\text {th }}$ grade. Tasks that made skills occur most frequently were aimed at the development of interpersonal competencies (almost 17\%), learning 
competencies $(15,9 \%)$ but mostly communicative competencies (almost $28 \%$ ). Within $8^{\text {th }}$ graders, as opposed to $6^{\text {th }}$ graders, a lower frequency of instances of harmonic relationships occurred, especially within groups consisting of boys. In some cases there was insufficiency in terms of reading comprehension, as pupils resolved the task actively, however irrationally without carefully reading the task. The pupils in this grade behaved honestly and responsibly as well, however there were some attempts at making the work easier and wait for the result on the IWB. Learning competencies also occurred (15,9\%). The pupils motivated one another and actively participated in task resolution. In contrast to the pupils of the $6^{\text {th }}$ grade, the cognitive competency - critical thinking $(11,15 \%)$ occurred more frequently amongst $8^{\text {th }}$ graders. The reason for this is the fact that from ontogenetic point of view these pupils reach a higher cognitive level than $6^{\text {th }}$ graders and their way of thinking allows them to analyse, synthesize and generalise.

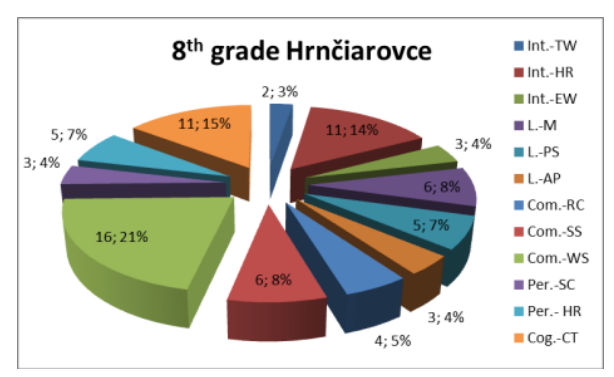

Fig. 2: Percentageoccurrence of the observed competencies in the 8 th grade at elementary school in HrnčiarovcenadParnou.

Another institution where we observed the effect of educational materials using IWB conducted by us with the aim of developing key competencies was the elementary school in Nitra.

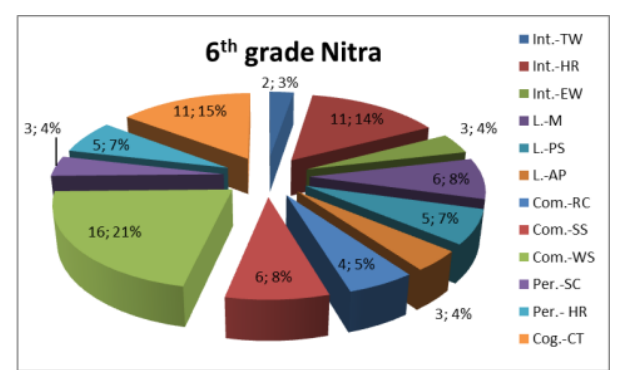

Fig. 3: Percentageoccurrence of observed competencies in the 6th grade in Nitra.

Fig. 3 shows that students of the $6^{\text {th }}$ grade predominantly showed communicative competencies (27,52\%) while resolving tasks regarding wood in the workbook. There occurredinterpersonal competencies $(16,84 \%)$ and also closely related learning competencies $(15,9 \%)$ as well. We observed lower degree of active participation in task resolving. Out of communication competencies we observed writing skills amongst $6^{\text {th }}$ graders. The pupils actively participated in communication within the team as well as with their teacher and other classmates. Similarly to $6^{\text {th }}$ graders from Hrnčiarovce, the pupils showed personal competencies $(9,1 \%)$; mostly honesty and responsibility for own behaviour and actions $(3,4 \%)$. In case of both $6^{\text {th }}$ and $8^{\text {th }}$ graders in Nitra, Cognitive competencies evincedthemselves at the same level $\left(6^{\text {th }}\right.$ grade $11,15 \%$, and $8^{\text {th }}$ grade $11,16 \%$ )

In the $8^{\text {th }}$ grade in Nitra (Fig. 4) the communicative competency could be observed most often - writing skills $(16,23 \%)$, team work $(7,10 \%)$, speaking skills $(6,9 \%)$. The pupils communicated actively within teams, however, less with their teacher and other classmates. Reading comprehension skills were similar to $6^{\text {th }}$ graders.

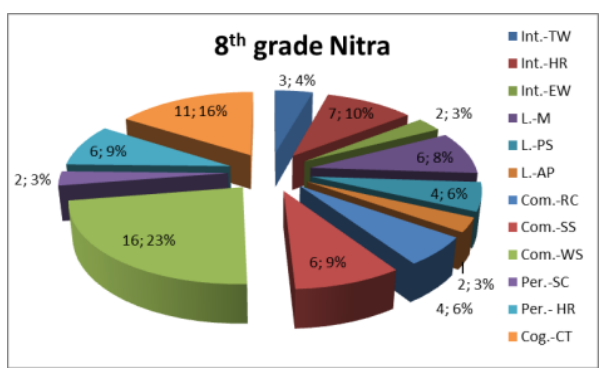

Fig. 4: Percentage occurrence of observed competencies in the 8th grade in Nitra.

Similarly to $6^{\text {th }}$ graders, $8^{\text {th }}$ graders have shown educational $(13,7 \%)$ as well as personal competencies $(9,2 \%)$. Amongst interpersonal competencies we were able to observe harmonic relationships $(3,4 \%)$ and work efficiency $(2,3 \%)$.

\section{Conclusion}

The partial results of the pilot research aimed at developing key competencies of elementary school pupils through IWB in the subject of Technics show that active use of this teaching model and implementation of educational materials for work with IWB conducted by us are relevant to the methodology of the subject of Technics as the tasks definitely help to develop the given key competencies and skills of pupils.

Nowadays, the idea of implementing IWB to the teaching process is nothing new [6]. However, the absence of educational materials and consequential inactivity of teachers working with IWBs is currently a crucial problem in Slovak Republic. Therefore, our objective was to create a teaching model which would not only provide suitable implementation of IWBs into the teaching process but also through which we actively support the development of key competencies of pupils. 


\section{Acknowledgements}

The article and the subject research are supported by through KEGA project nr. 015PU-4/2013Methodology for implementation of interactive whiteboards in training to competences in teacher training techniques, physics and mathematics for lower secondary education.

\section{References}

[1] P. Brečka, "Interaktívnetabule v technickomvzdelávaní," IRIS 2014. ISBN 978-808153-024-1.

[2] M. Belčík and I. Tureková, "Faktoryovplyvňujúcevýkončloveka a spôsobichaplikácie," Konference bezpečnostni management a společnost, Brno, Univerzitaobrany, pp. 46-51. 2013. ISBN 978-80-7231-928-2.
[3] $\mathbf{J}$ rozvojvybranýchkl'účovýchzručnostížiakovnahodinách Techniky,"EdukacjaTechnika - Informatyka. Rzeszów: Fosze, 2013.

[4] I. A. Filipe, "Unexpected learning competencies of Grades 5 and 6 pupils in public elementary schools: A Philippine report," International Education Journal, Vol. 7, Issue 7, pp. 957-966, 2006.

[5] A. Harlow, B. Cowie, M. and Heazlewood, "Keeping in touch with learning: The use of an IWB in the junior school," Technology, Pedagogy and Education, Vol. 19, Issue 2, pp. 237-243, 2010.

[6] P. Brečka and M. Olekšáková, "Implementation of IWB into the Educational Systems at Primary and Secondary Schools in the Slovak Republic," Proc. of the 2013 International Conference on Advanced ICT and Education, Vol. 33, pp. 126-130, 2013. ISSN 19516851. 